\title{
The municipal solid waste landfill as a source of ozone-depleting substances in the United States and United Kingdom
}

\author{
E. L. Hodson ${ }^{1, *}$, D. Martin ${ }^{2, * *}$, and R. G. Prinn ${ }^{1}$ \\ ${ }^{1}$ Department of Earth, Atmospheric and Planetary Sciences, Massachusetts Institute of Technology, 77 Massachusetts \\ Avenue, Cambridge, MA 02139, USA \\ ${ }^{2}$ School of Chemistry, University of Bristol, Bristol BS8 1TS, UK \\ *now at: Swiss Federal Research Institute WSL, Zuercherstrasse 111, 8903 Birmensdorf, Switzerland \\ ** now at: Centre for Climate and Air Pollution Studies, Environmental Change Institute, National University of Ireland, \\ Galway, Ireland
}

Received: 1 October 2009 - Published in Atmos. Chem. Phys. Discuss.: 27 October 2009

Revised: 28 January 2010 - Accepted: 5 February 2010 - Published: 19 February 2010

\begin{abstract}
This study provides observation-based national estimates of CFC-11, CFC-12, CFC-113, and 1,1,1trichloroethane emissions for the United States (US) and United Kingdom (UK) from municipal solid waste (MSW) landfills. The scarcity of national estimates has lead to the assumption that a significant fraction of the lingering ozonedepleting substance (ODS) emissions, which have been detected in industrialized countries, could be emitted from landfills. Spatial coverage was achieved through sampling at seven landfills in Massachusetts and through data provided by nine UK landfills. Linear least square regressions of recovered ODS vs. $\mathrm{CH}_{4}$ were used in combination with national estimates of landfill $\mathrm{CH}_{4}$ emissions to estimate 2006 national US and UK ODS landfill emissions. The ODS landfill emission estimates were then compared to recent estimates of total US and UK ODS emissions. US ODS landfill emissions are $0.4 \%-1 \%(0.006-0.09 \mathrm{Gg} /$ year $)$ of total US emissions. UK ODS landfill emission estimates are $1 \%$ $(0.008 \mathrm{Gg} /$ year $)$ and $6 \%(0.03 \mathrm{Gg} /$ year $)$ of total UK CFC- 11 and CFC-12 emissions, respectively. This indicates that landfills are only a minor source of lingering ODS emissions in the US, but may be more significant for CFC-12 emissions in the UK. The implication is that the majority of current ODS emissions in industrialized countries is likely coming from equipment still in use.
\end{abstract}

Correspondence to: E. L. Hodson (elkeh@alum.mit.edu)

\section{Introduction}

The Montreal Protocol has had great success in reducing global emissions of ozone-depleting gases since it came into effect in industrialized countries in the mid-1990s. The rate of accumulation of ozone-depleting substances (ODSs) in the troposphere has declined to the point where tropospheric concentrations are now stable or decreasing (AGAGE, 2009). However, ODSs continue to be important to the study of stratospheric ozone recovery and to climate change. In particular, accurate predictions of future ODS emissions are needed to devise strategies which could minimize stratospheric ozone loss and greenhouse gas (GHG) emissions over the coming decades.

The four ODSs considered in this study are CFC11 (trichlorofluoromethane), CFC-12 (dichlorodifluoromethane), CFC-113 (1,1,2-trichloro-1,2,2-trifluoroethane), and $\mathrm{CH}_{3} \mathrm{CCl}_{3}$ (1,1,1-trichloroethane). It is the combination of high ozone depleting potential (ODP), the large volume historically released to the atmosphere, and their long lifetimes which make chlorofluorocarbons (CFCs) still highly important to the study of ozone recovery. CFC-11 and CFC-12 continue to have the highest global background concentration of the Montreal Protocol gases, and only HCFC-22 has surpassed CFC-113 (AGAGE, 2009). $\mathrm{CH}_{3} \mathrm{CCl}_{3}$ concentrations have decreased sharply in recent years so that it is no longer as important a factor in ozone recovery, but it remains important as a method of estimating $\mathrm{OH}$ mole fractions (Prinn et al., 2005; Bousquet et al., 2005; Wang et al., 2008). With regard to climate, CFCs have very high global warming potentials (GWPs), exerting

Published by Copernicus Publications on behalf of the European Geosciences Union. 
$\sim 5000-15000$ times the effect which the same amount of added $\mathrm{CO}_{2}$ would have on warming the atmosphere over 100 years (WMO, 2007).

As the Montreal Protocol has come into effect and production of ODSs has decreased sharply, "banks" have become a significant source of future projected CFC emissions. Banks comprise products still in use, stockpiled products in case of equipment replacement, and discarded products in landfills. An increase in estimated CFC banks (i.e. by $\sim 1100 \mathrm{Gg}$ for CFC-11 and $700 \mathrm{Gg}$ for CFC-12 for the year 2002) is considered to be a significant cause for the recent increase (by 5 years) in projected ozone recovery time compared to previous ozone recovery estimates (WMO, 2007; Daniel et al., 2007).

Landfills have the potential to be important emitters of banked ODSs. CFC-11, CFC-12, CFC-113, and $\mathrm{CH}_{3} \mathrm{CCl}_{3}$ have all been detected in landfill gas significantly above ambient concentrations (Rettenberger and Stegmann, 1996; Allen et al., 1997; Giess et al., 1999; Scheutz et al., 2008; and references therein). Major landfilled products include aerosol cans (propellant residue), refrigerant liquid, and foams (mainly polystyrene) for CFC-12; aerosol cans, closed cell polyurethane foam (e.g. refrigeration insulation), soft foam plastics (e.g. furniture and mattresses) for CFC-11; solvent residues (e.g. dry-cleaning), foams, refrigerant, and propellant for CFC-113; and solvent residues (e.g. stain removers, detergents, adhesives, lacquers) for $\mathrm{CH}_{3} \mathrm{CCl}_{3}$ (Deipser et al., 1996; McCulloch and Midgley, 1998; McCulloch et al., 2001, 2003; IPCC/TEAP, 2005).

There have been significant advances in the understanding of processes controlling the magnitude and timing of CFC and $\mathrm{CH}_{3} \mathrm{CCl}_{3}$ landfill emissions, but more in-situ measurements are still needed. Several laboratory studies have investigated parameters important to the study of CFC landfill emissions. The size of shredded foam has been shown to have a large influence on the release time of CFC-11, which could delay landfill emissions by at least several decades (McCulloch et al., 2001; Kjeldsen and Jensen, 2001; Kjeldsen and Scheutz, 2003). All of the compounds in this study have been shown to degrade under simulated anaerobic landfill conditions (Deipser and Stegmann, 1997; Scheutz and Kjeldsen, 2003; Scheutz et al., 2007), but the effects in-situ are just beginning to be investigated (Scheutz et al., 2008). ODS concentrations have been measured in-situ and several countries have default national landfill concentration values for individual ODSs (Parker et al., 2002; EPA, 2008). There are far fewer site-specific in-situ measurements of CFC and $\mathrm{CH}_{3} \mathrm{CCl}_{3}$ emissions (EPA, 1995; Allen et al., 1997; EPA, 2009b). The United States Environmental Protection Agency maintains an online model which can estimate single landfill emissions for a range of ODSs (EPA, 2009c). Yet, as of the latest assessment report from the Intergovernmental Panel on Climate Change, there were no existing national inventory methods to quantify national ODS emissions from landfills (Bogner et al., 2007).
In this study, we estimate national emission rates from MSW landfills for two industrialized countries with significant landfilling of waste, the US and UK. National MSW landfill emissions are based on whole landfill mole fractions and flow rates, which were collected from US and UK landfills during the fall of 2006. The data was used to create linear regressions of ODS and methane $\left(\mathrm{CH}_{4}\right)$ recovery rates. These regressions, combined with national estimates of landfill $\mathrm{CH}_{4}$ emissions, yielded national estimates of MSW landfill emissions of ODSs for the US and UK.

\section{Methods}

\subsection{Design of study}

Estimating emissions of CFC-11, CFC-12, CFC-113, and $\mathrm{CH}_{3} \mathrm{CCl}_{3}$ from landfills in industrialized countries required a targeted approach. Because any field sampling would only cover a fraction of the more than 1800 open landfills in 2006 in the US (Arsova et al., 2008), it was important to design the field study carefully to achieve the most unbiased estimates possible.

The study focused on estimating landfill ODS emissions for the US, with one-time field sampling at several US MSW landfills as well as monthly sampling for over one year at one US MSW landfill. Data was made available for several UK MSW landfills to provide a comparison with another industrialized country.

To narrow the focus of the study, we decided to sample or collect information from non-hazardous waste landfills which accept more than $50 \%$ of their waste from domestic and commercial sources (MSW landfills). In the US, MSW landfills account for over $90 \%$ of total generated landfill gas (EPA, 1994, 2009a,d). Within MSW landfills, sampling was constrained to landfills which pumped their landfill gas to the surface (active gas collection) to increase the number of measurements for statistical analysis.

In order to sample a representative cross section of US and UK landfills, we controlled for two important variables, namely landfill age and total landfilled waste, as shown in Fig. 1 in the Supplementary Information (SI) http://www.atmos-chem-phys.net/10/1899/ 2010/acp-10-1899-2010-supplement.pdf. The intention was to sample a cross-section of small, medium, and large landfills covering a range of ages. On average, the US study sites in the state of Massachusetts were older and had less landfilled waste than the national average. The UK study sites were better distributed with respect to total landfilled waste, but were younger than the US landfills.

\subsection{Study sites}

The sample sites consisted of seven US and nine UK MSW landfills with active gas management. The detailed demographic information for each landfill is shown in Table 1 

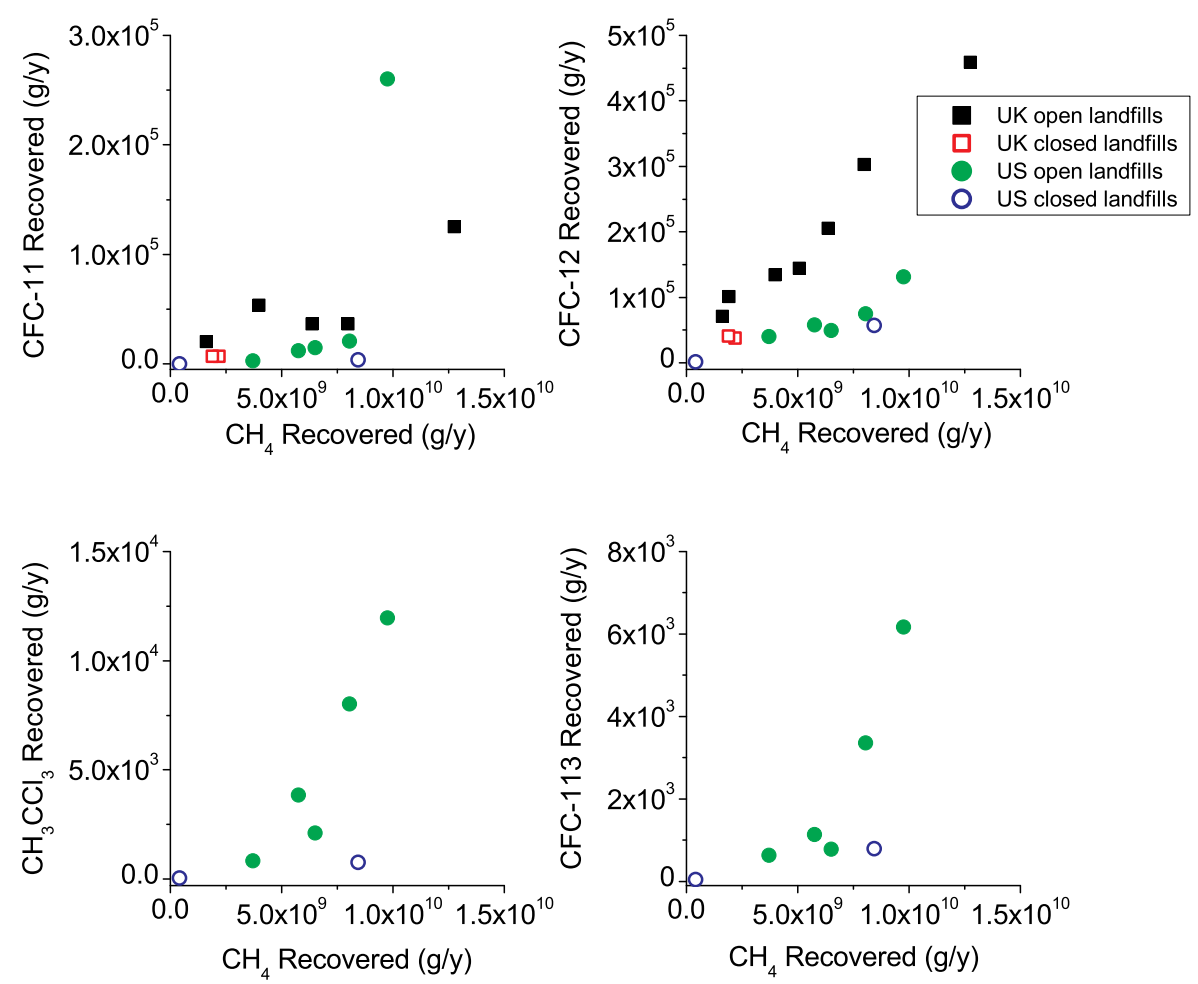

Fig. 1. Recovered CFC-11, CFC-12, CFC-113, and $\mathrm{CH}_{3} \mathrm{CCl}_{3}$ plotted against recovered $\mathrm{CH}_{4}$ for all US and UK landfill sites. Note the varying $\mathrm{y}$ axis scales.

in the SI http://www.atmos-chem-phys.net/10/1899/2010/ acp-10-1899-2010-supplement.pdf. The UK sites are all owned by one landfill company, while the US sites are partly municipal and partly privately owned landfills. Two US (landfills 5 and 6) and two UK (landfills 8 and 9) landfills had reached capacity and no longer accepted waste at the time of sampling. The accounting of the type of waste which is landfilled is slightly different for the US and UK. For the UK landfills, domestic and I/C (industrial and commercial) are the two main waste categories, while for the US landfills, MSW, which includes domestic and commercial waste, is the dominant category. For this study, US landfills with more than 50\% MSW and UK landfills with more than 50\% domestic waste were considered MSW landfills.

\subsection{Measurement data}

Table 1 presents data for each sample site. All of the mole fractions and flow rates are whole landfill averages, which were obtained by sampling at ports located on the main gas line directly before either the flare or the gas-to-energy plant. For the US sites, all of the data shown in Table 1 was used for the emission estimates. Multiple sample dates per site were averaged to yield one data point. For the UK sites, only the data from 2006 and 2007 was used for the emission estimates because of high year-to-year variability in the CFC-11 mole fractions at several sites. UK data from 2004 is added as a comparison. CFC-12 mole fractions within each UK sample sites showed almost no year-to-year variability within landfill sites. This was also observed in a 1.5 year variability study (Hodson, 2008) and may be related to lower microbial degradation rates for CFC-12 compared to CFC-11 (Scheutz and Kjeldsen, 2003; Scheutz et al., 2007). Flow rates in Table 1 are yearly averages for 2006 and are the ones used in the subsequent analyses to calculate emissions.

A 1.5 year-long study (not shown) at US landfill 2 was undertaken during 2005-2006 to monitor the intra-annual variability of ODS, $\mathrm{CH}_{4}$, and flow rates and to lend credibility to the following emission estimates, which used data from onetime field sampling. The standard deviation on the mean of the monthly-sampled landfill mole fractions was 19\% (CFC12), $29 \%$ (CFC-11), $23 \%$ (CFC-113), $12 \%\left(\mathrm{CH}_{3} \mathrm{CCl}_{3}\right)$, and $2.8 \%\left(\mathrm{CH}_{4}\right)$, while the standard deviation for the flow rate was $12.5 \%$. The variability increased (up to $45 \%$ ) for all ODSs in this study except for CFC-12, when a flare was used as the end-of-pipe technology instead of a reciprocating engine (Hodson, 2008).

\subsection{US gas collection and analysis}

Data collection for the US and UK landfill sites was considerably different. For each of the seven US sample sites, 
Table 1. US and UK landfill gas mole fractions and flow rates ${ }^{\mathrm{a}}$.

\begin{tabular}{|c|c|c|c|c|c|c|c|c|}
\hline \multirow[b]{2}{*}{ Site } & \multicolumn{2}{|l|}{ Sample } & \multirow{2}{*}{$\begin{array}{r}\text { CFC-11 } \\
(p p b)\end{array}$} & \multicolumn{3}{|c|}{ CFC-113 } & \multirow{2}{*}{$\begin{array}{r}\mathrm{CH}_{4} \\
(\%)\end{array}$} & \multirow{2}{*}{$\begin{array}{r}\text { Flow } \\
\text { Rate }^{\mathrm{c}} \\
\left(\mathrm{Nm}^{3} \mathrm{y}^{-1}\right)\end{array}$} \\
\hline & Date & $\mathrm{N}^{\mathrm{b}}$ & & $\begin{array}{r}\text { CFC-12 } \\
(\mathrm{ppb})\end{array}$ & (ppb) & $\begin{array}{r}\mathrm{CH}_{3} \mathrm{CCl}_{3} \\
(\mathrm{ppb})\end{array}$ & & \\
\hline \multicolumn{9}{|c|}{ US sites } \\
\hline 1 & 20.11 .06 & 9 & 1500 & 850 & 26 & 70. & 47.3 & $2.88 \mathrm{E} 7$ \\
\hline 2 & $2006^{\mathrm{d}}$ & 108 & 140 & 730 & 9.3 & 44 & 55.0 & $1.46 \mathrm{E} 7$ \\
\hline 3 & 19.12 .06 & 9 & 130 & 490 & 5.0 & 19 & 48.6 & $1.87 \mathrm{E} 7$ \\
\hline 4 & 28.11 .06 & 9 & 36 & 580 & 6.0 & 11 & 40.7 & $1.27 \mathrm{E} 7$ \\
\hline \multirow[t]{2}{*}{5} & 19.10 .06 & 9 & 160 & 590 & 15 & 74 & 50.4 & $2.34 \mathrm{E} 7$ \\
\hline & 18.12 .06 & 9 & 130 & 600 & 20. & 40. & 45.5 & $2.34 \mathrm{E} 7$ \\
\hline 6 & 31.10 .06 & 9 & 25 & 410 & 3.7 & 4.9 & 45.4 & $2.59 \mathrm{E} 7$ \\
\hline 7 & 20.11 .06 & 9 & 24 & 200 & 4.7 & 7.2 & 46.0 & $1.26 \mathrm{E} 6$ \\
\hline \multicolumn{9}{|c|}{ UK sites } \\
\hline 1 & 21.03 .06 & 1 & 360 & 2300 & ND & ND & 52.8 & $1.68 \mathrm{E} 7$ \\
\hline \multirow[t]{2}{*}{2} & 2004 & 1 & 210 & 1800 & ND & ND & NM & $1.48 \mathrm{E} 7$ \\
\hline & 03.05 .07 & 1 & ND & 1800 & ND & ND & 47.8 & $1.48 \mathrm{E} 7$ \\
\hline 3 & 10.01 .07 & 1 & 300 & 2800 & ND & ND & 56.2 & $1.98 \mathrm{E} 7$ \\
\hline 4 & 07.04 .06 & 1 & ND & 2800 & ND & ND & 40.4 & $6.61 \mathrm{E} 7$ \\
\hline \multirow[t]{2}{*}{5} & 23.04 .04 & 1 & 320 & 2500 & ND & ND & NM & $3.82 \mathrm{E} 7$ \\
\hline & 03.05 .07 & 1 & 530 & 2200 & ND & ND & 46.6 & $3.82 \mathrm{E} 7$ \\
\hline \multirow[t]{2}{*}{6} & 28.06 .04 & 1 & 940 & 2300 & ND & ND & NM & $1.12 \mathrm{E} 7$ \\
\hline & 07.04 .06 & 1 & 780 & 2200 & ND & ND & 49.6 & $1.12 \mathrm{E} 7$ \\
\hline 7 & 07.04 .06 & 1 & 590 & 2300 & ND & ND & 39.5 & $5.69 \mathrm{E} 6$ \\
\hline 8 & 07.04 .06 & 1 & 200 & 1200 & ND & ND & 51.3 & $5.95 \mathrm{E} 6$ \\
\hline 9 & 21.03 .06 & 1 & 250 & 1600 & ND & ND & 55.6 & $4.71 \mathrm{E} 6$ \\
\hline
\end{tabular}

${ }^{a}$ Units are parts per billion (ppb), \% total gas stream by volume (\%), and normal cubic meters per year $\left(\mathrm{Nm}^{3} \mathrm{y}^{-1}\right)$. ND $=$ not detectable and indicates that concentrations were below the UK analysis detection limit of $1 \mu \mathrm{g} \mathrm{m}^{-3}$. NM= not measured.

$\mathrm{b}$ Number of gas analyses which were averaged to yield the mole fractions on the corresponding rows.

${ }^{c}$ Represents yearly averaged flow rates for 2006 corrected for seasonal variability.

${ }^{\mathrm{d}}$ US site 2 sampled monthly in 2006.

we collected and analyzed triplicate canister samples during the fall of 2006. The canister samples were collected in $0.8 \mathrm{~L}$ electropolished stainless steel cylinders filled in succession to 30 psig using a metal-bellows pump on a sampling line already flushed with the sample landfill gas. Three-fold evacuations to $100 \mathrm{~m}$ Torr of each sample canister as close as possible to the time of sampling ensured canister cleanliness. Selected canisters were analyzed for lingering traces of $\mathrm{CH}_{4}$ to further prohibit cross-contamination between sampling.

The US gas samples were analyzed on an AGILENT 6890 gas chromatograph with both a flame ionization detector (FID) and a micro electron capture detector ( $\mu$-ECD). Samples analyzed for CFC-11, CFC-12, CFC-113 and $\mathrm{CH}_{3} \mathrm{CCl}_{3}$ were introduced by static fixed loop injection $(50 \mu \mathrm{l}$, inject time $=30 \mathrm{~s}$ ), with separation on a $25 \mathrm{M} \times 0.32 \mathrm{~mm}$ ID CP Sil 5 CB capillary column followed by detection by $\mu \mathrm{ECD}$. The GC oven program was $45^{\circ} \mathrm{C}$ for $1 \mathrm{~min}, 10^{\circ} \mathrm{C} / \mathrm{min}$ to $100^{\circ} \mathrm{C}$, hold at $100^{\circ} \mathrm{C}$ for $0.5 \mathrm{~min}, 30^{\circ} \mathrm{C} / \mathrm{min}$ to $200^{\circ} \mathrm{C}$, and hold at $200^{\circ} \mathrm{C}$ for $1 \mathrm{~min}$. $\mathrm{CH}_{4}$ was analyzed by static fixed loop injection $(10 \mu \mathrm{l}$, inject time $=4.8 \mathrm{~min})$ followed by separation on a $50 \mathrm{M} \times 0.32 \mathrm{~mm}$ i.d. Alumina $\left(\mathrm{Al}_{2} \mathrm{O}_{3}\right)$ PLOT column $\left(\mathrm{Na}_{2} \mathrm{SO}_{4}\right.$ modified) at an isothermal oven temperature of $45^{\circ} \mathrm{C}$.
Samples were analyzed in triplicate and bracketed by calibration standards. The ODS standard (Scott specialty gases) contained CFC-11, CFC-12, CFC-113 and $\mathrm{CH}_{3} \mathrm{CCl}_{3}$ all at certified accuracy of better than $5 \% . \mathrm{CH}_{4}$ was calibrated using pure standard (research grade, $99.999 \%$ pure, BOC gases).

Calibration curves were constructed over the experimental range for the ODS measurements and these were applied to analytical samples. The limits of quantitation (signal $/$ noise $=10$ ) were $0.57 \mathrm{ppb}$ for the ODSs and $1330 \mathrm{ppb}$ for $\mathrm{CH}_{4}$. All samples measured exceeded these values. Average measurement precision for the GC- $\mu \mathrm{ECD} / \mathrm{FID}$ was $0.95 \%$ (CFC-12), $0.90 \%$ (CFC-11), 2.5\% (CFC-113), $2.9 \%$ $\left(\mathrm{CH}_{3} \mathrm{CCl}_{3}\right)$ and $0.47 \%\left(\mathrm{CH}_{4}\right)$.

\subsection{UK gas collection and analysis}

CFC-11, CFC-12, and $\mathrm{CH}_{4}$ mole fractions for the nine UK landfills were obtained from Viridor Waste Management. All of the data from Viridor had well documented sampling and analysis procedures, but had only one analysis per sample date. For the gas samples collected before May of 2007, Viridor collected the sample and CERAM (Stoke-on-Trent, Staffordshire, UK) performed the analysis. 
CERAM is a UKAS (United Kingdom Accreditation Service) ISO 17 025:2005 accredited testing laboratory specializing in landfill gas analysis. Viridor filled one or more Tedlar bags using a GA2000 Infrared Gas Analyzer (Geotechnical Instruments, Chelmsford, England) fitted with a water filter. The bags were filled to $\sim 3 \mathrm{~cm}$ thick and shipped to CERAM. At CERAM, the gas samples were analyzed using their UKAS in-house method BCRL-C51 and BCRL-C72 for the $\mathrm{CFCs}$ and $\mathrm{CH}_{4}$, respectively. Both methods were accredited in 1999. All of the gas samples were analyzed on a GCMS at most two weeks after sampling.

For the two UK samples analyzed in May of 2007, C\&P Environmental (Bedford, Bedfordshire, UK) collected the samples and performed the analysis. C\&P used a GA2000+ analyzer to fill and evacuate their Tedlar bags two or more times before filling the final sample. Two Tedlar bags were filled in case one leaked before the gas analysis. Bags were kept at ambient temperature in a dark, cool box during transportation after sampling and before analysis. Analysis was done one week after sampling on a GC-MS at C\&P Environmental which is an UKAS accredited testing laboratory.

\subsection{Flow rates}

For US landfills 1-6, instantaneous flow rates were provided by the landfill operators and extrapolated to yearly averages. A comparison at US landfill 2 between the built-in, continuous monitoring orifice plate (accuracy $\pm 0.6 \%$ of flow, Oripac Model, Lambda Square Inc., Bay Shore, NY, USA) and a traverse with a Dwyer 166 T Telescoping Pitot Tube (Dwyer Instruments Inc, Michigan City, IN, USA) combined with a Dwyer 477A-1 Handheld Digital Manometer (scale 0 “ -20 " water column, accuracy is $0.1 \%$ full scale) yielded flow rates within 4\%. Landfills 1-6 all had similar built-in flow monitoring technologies. US landfill 7 had only a flare and no built-in flow monitoring technology. Thus, the flow rate for landfill 7 was measured with the Dwyer pitot tube and manometer.

For the UK, Viridor provided yearly averaged flow rates for each site. The flow rates were given in units of normal meters cubed per year $\left(1 \mathrm{~atm}\right.$ and $\left.0{ }^{\circ} \mathrm{C}\right)$. Viridor did not measure daily flow rates, but rather used a model to calculate annual emissions based on input parameter including landfill size, depth, age of waste, and type of landfilled waste. Estimated error on the annual flow projections is 10-20\%.

It was necessary to standardize the US and UK data sets by calculating 2006 annual averages of flow rates for each landfill. The US instantaneous flow rates were converted into average annual flow rates using seasonal correction factors derived from the long term study at US landfill 2. Flow rates were averaged in the long term study for 30 days before and after the sample date of the flow rate to be corrected. The average ratio between the 60 days and running 12-month averages (calculated from 18 months of gas-to-energy plant data for US landfills 1-6 and 3 years of flare data for US land- fill 7) was then applied to the data set to be corrected. No corrections were necessary for the annual averaged flow rates obtained for the UK landfills.

\subsection{Emission estimation methodology}

The fate of landfill $\mathrm{CH}_{4}$ and ODSs can be expressed by the following simplified equations

$\mathrm{CH}_{4(\text { emitted })}=\mathrm{CH}_{4(\text { produced })}-R-\mathrm{O}_{\mathrm{x}}$

$\operatorname{ODS}_{(\text {emitted })}=\operatorname{ODS}_{(\text {volatilized })}-R-\mathrm{Md}$

where $R=$ recovered $\mathrm{CH}_{4}$ or ODS, $\mathrm{O}_{\mathrm{x}}=\mathrm{CH}_{4}$ oxidized in the landfill soil cover, and $\mathrm{Md}=$ microbial degradation of the respective ODSs (Bogner et al., 2007; Scheutz et al., 2007, and references therein). Two further pathways important on longer time scales are lateral migration underground and internal changes in landfill gas storage (Bogner et al., 2007). Recovered landfill gas is defined as the gas generated within the landfill which is pumped to a flare or gas-to-energy plant for combustion or electricity conversion.

In this study, we measured recovered ODS and $\mathrm{CH}_{4}$ gas fluxes and made use of available national inventory statistics for landfill $\mathrm{CH}_{4}$ to scale the individual measurements to national landfill ODS emissions. This bootstrap method can be expressed as

$\mathrm{ODS}_{(\mathrm{emitted})}=\frac{\mathrm{ODS}_{\text {(recovered })}}{\mathrm{CH}_{4}(\text { recovered })} \times \mathrm{CH}_{4 \text { (emitted })}$

where all units are in mass/time.

This bootstrap method allowed us make use of available inventory data and landfill gas technology, but includes assumptions for our results. First, we assumed that the $\mathrm{ODS} / \mathrm{CH}_{4}$ ratio was the same in the recovered and emitted landfill gas. To check this assumption, we calculated $\mathrm{ODS} / \mathrm{CH}_{4}$ ratios for our five US open landfills using the US Environmental Protection Agency (EPA) landfill gas emissions model LandGEM (EPA, 2009c). We then compared the LandGEM emission ratios and the recovered gas ratios from this study to surface emission ratios and recovered gas ratios which were measured at Freshkills landfill in New York (EPA, 1995). Table 2 in the SI presents the results http://www.atmos-chem-phys.net/10/1899/2010/ acp-10-1899-2010-supplement.pdf. The ratio of ODS/CH was within $25 \%$ from all data sources for CFC-12, CFC113 , and $\mathrm{CH}_{3} \mathrm{CCl}_{3}$. CFC-11/CH $\mathrm{CH}_{4}$ ratios were $130 \%$ higher in the gas collection system compared to the emitted gas at Freshkills landfill (EPA, 1995). Likewise, the CFC-11/CH ratio in this study was $60 \%$ higher than the predicted emissions from the LandGEM model. One reason for this difference in ratio variability may come from recent studies of anaerobic degradation. In simulated landfill soil cover and anaerobic landfill conditions, CFC-11 degradation is faster than CFC-12 degradation and methane oxidation (Scheutz and Kjeldsen, 2003; Scheutz et al., 2007). Moreover, a recent 
field study observed very constant soil concentration profiles to a depth of $80 \mathrm{~cm}$ for CFC-113 and $\mathrm{CH}_{3} \mathrm{CCl}_{3}$ (Scheutz et al., 2008). Taking the more conservative ratio, we would expect our CFC-11 emission estimates to overestimate emissions by approximately $130 \%$ and that our CFC-12, CFC113 , and $\mathrm{CH}_{3} \mathrm{CCl}_{3}$ estimates would be within $25 \%$ of their true values.

A second assumption with our method is that the combustion efficiencies of the recovered $\mathrm{CH}_{4}$ and ODSs are the same. The US landfill $\mathrm{CH}_{4}$ inventory data assumes a combustion efficiency of 99\% (EPA, 2009a) and the UK landfill $\mathrm{CH}_{4}$ inventory data assumes a total percentage of recovered landfill gas nationally (Choudrie et al., 2008). Studies of CFC combustion efficiency at typical flare and engine operating temperatures achieve destruction efficiencies greater than 99.9\% (Rittmeyer and Vehlow, 1993), which matches assumed $\mathrm{CH}_{4}$ combustion efficiencies within $1 \%$.

The national inventory statistics for emitted landfill $\mathrm{CH}_{4}$ along with their confidence intervals, which were used for this study, are shown in Table 2. Both the US and UK estimates calculate landfill $\mathrm{CH}_{4}$ emissions using a more complex version of Eq. (1). The best estimates in Table 2 include all of the parameters in Eq. (1). The maximum estimates do not subtract recovered $\mathrm{CH}_{4}(R)$ or oxidized $\mathrm{CH}_{4}\left(\mathrm{O}_{\mathrm{x}}\right)$. The fraction of recovered landfill gas is provided by both estimates and is calculated using available flare and gas-to-energy plant databases and through consultations (Choudrie et al., 2008; EPA, 2009a). A second US $\mathrm{CH}_{4}$ estimate from EIA (2008) was not included in Table 2 because it was only 5.7\% higher than the EPA (2009a) estimate and did not provide either a maximum estimate or annually updated confidence intervals. Both estimates in Table 2 include $\mathrm{CH}_{4}$ emissions primarily from MSW, but also from industrial and commercial waste. Even if it would have been possible to attribute $\mathrm{CH}_{4}$ emissions to each waste type, our sampled landfills also contained mixed waste sources. Thus, while our study is biased towards municipal solid waste emissions, our results also include some influence from commercial and industrial waste sources. This increases the uncertainty on our ODS emission estimates, but also generalizes our results to landfills beyond MSW landfills.

Several other bootstrap parameters besides total emitted landfilled $\mathrm{CH}_{4}$ were considered such as total and annual landfilled waste, landfill age, megawatt capacity of gas-toenergy plants, and total landfill surface area. Estimates made using landfilled waste are presented in the SI. Their major disadvantage was that they did not allow subtraction of the recovered fraction of landfill gas. Landfill age did not have a linear relationship with ODS recovery rates and it was reported in a partially audited database (LMOP, 2009). It is possible that landfill age might be useful as a secondary parameter in a multiple linear regression, but the small sample size for this study did not support anything more complicated than using a single linear relationship for scaling to emission estimates. Megawatt capacity is also reported in the same
Table 2. 2006 US and UK national estimates of $\mathrm{CH}_{4}$ emissions from landfills.

\begin{tabular}{llrrr}
\hline & & \multicolumn{2}{c}{ Estimate Mean } & \\
\cline { 3 - 3 } Country/Source & $\begin{array}{r}\text { Best } \\
\left(\mathrm{Gg} \mathrm{y}^{-1}\right)\end{array}$ & $\begin{array}{r}\text { Maximum } \\
\left(\mathrm{Gg} \mathrm{y}^{-1}\right)\end{array}$ & $\begin{array}{r}\text { 95\% CIs } \\
\text { Upper, Lower }\end{array}$ \\
\hline US & EPA (2009a) & 6211 & 12543 & $+33 \%,-39 \%$ \\
UK & $\begin{array}{l}\text { Jackson et } \\
\text { al. (2008) }\end{array}$ & 926.5 & 3309 & $+20 \%,-20 \%$ \\
\hline
\end{tabular}

a The maximum estimate includes $\mathrm{CH}_{4}$ which is oxidized and recovered and is explicitly calculated by EPA (2009a). For the UK, the maximum estimate is calculated by assuming the best estimate is $30 \%$ of potential $\mathrm{UK} \mathrm{CH}_{4}$ emissions (Choudrie et al., 2008).

b $\mathrm{CI}=$ confidence interval. The US CIs are for $\mathrm{CH}_{4}$ emitted from landfills only, while the UK CIs were calculated for all $\mathrm{UK} \mathrm{CH}_{4}$ sources and are equal to $\pm 2 \times$ (standard deviation)/mean $\%$ ( $\sim 95 \%$ confidence interval) (Jackson et al., 2008).

partially audited database as landfill age. There is no national annual estimate of total landfill surface area.

Scatter plots of recovered ODSs vs. $\mathrm{CH}_{4}$ for all of the sample sites are shown in Fig. 1. The data is separated into four categories, including US, UK, open and closed landfills. The sampled US landfills emitted statistically significantly less CFC-12 per unit mass of $\mathrm{CH}_{4}$ than the UK landfills. This could indicate either 1) UK landfills release CFC-12 faster than US landfills due to age, climate, engineering design, etc.; or 2) that the UK waste has more total CFC-12 landfilled mass at least in the sample sites. For CFC-11, the comparison between countries was less clear because of one highly concentrated US site. If we compare open and closed landfills, not all of the compounds had the same ODS/CH $\mathrm{CH}_{4}$ ratio between the two landfill types. In particular, CFC-113 and $\mathrm{CH}_{3} \mathrm{CCl}_{3}$ closed and open landfills could not be included in the same linear regression. Even for CFC-12 and CFC-11 in the US data sets, with only two closed landfill data points and one of the two emitting almost no gas, it was difficult to evaluate if our US closed landfill data were reliable indicators of all closed US landfills. Thus, for the following analysis, the US and UK data sets were analyzed separately. Each data set was used to provide quantitative estimates for its respective country only. Furthermore, except for the UK CFC-11 data set, only open landfills were used to develop the linear regressions used in the methane bootstrap method (Eq. 3).

The six linear regressions for each ODS and country combination are presented in Fig. 2. The regression method used in this study was weighted linear least squares, which is appropriate for predicting a dependent variable (recovered ODS) given an independent variable (recovered $\mathrm{CH}_{4}$ ) (Isobe et al., 1990). The regression for UK CFC-11 was the only one which included closed landfills. Adding the closed landfills did not change the mean regression fit or the final mean emission estimates, but it did significantly reduce 

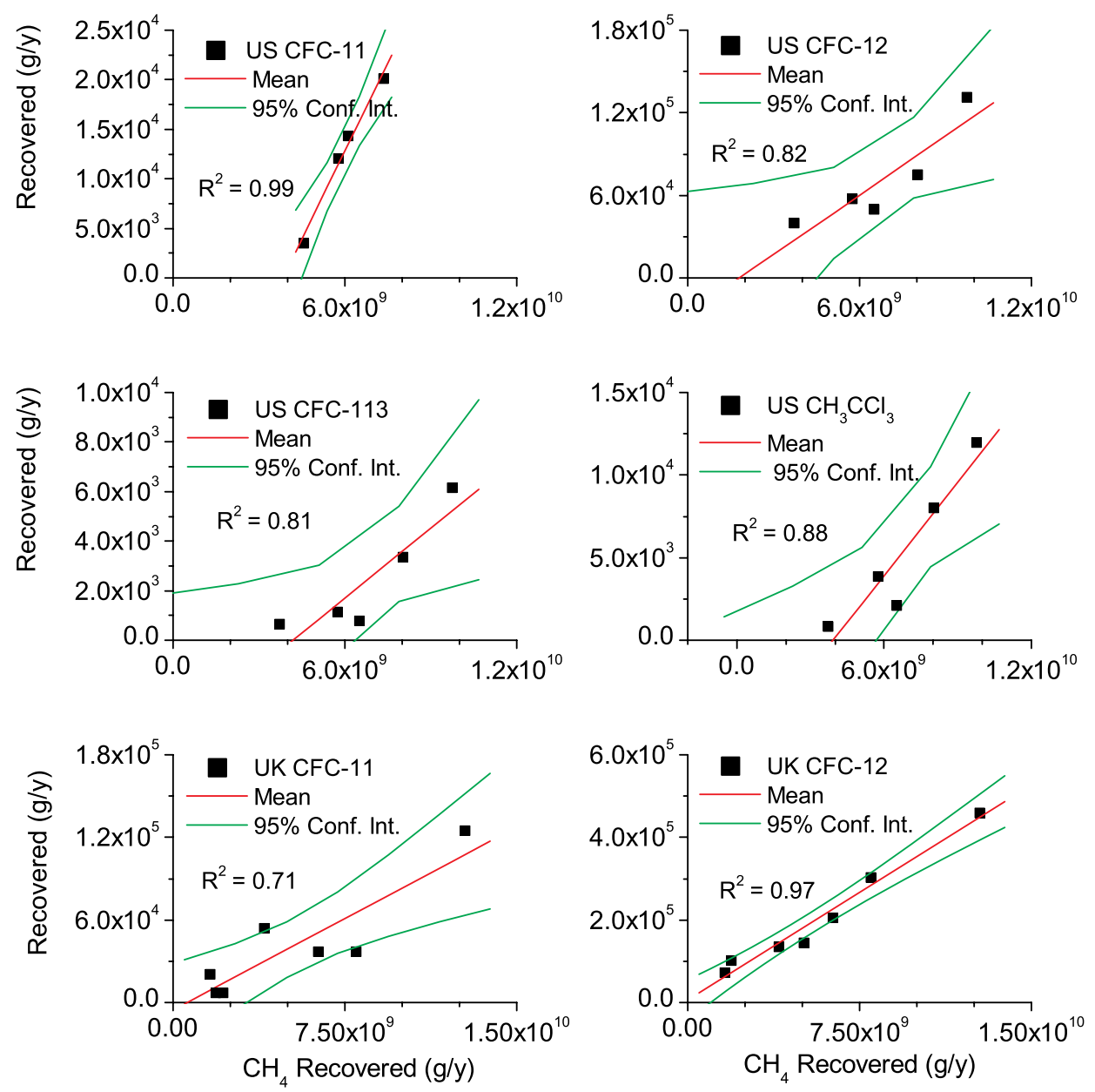

Fig. 2. Mean linear regression (red line), regression 95\% confidence intervals (green lines), and regression fit $\left(R^{2}\right)$ for each labeled country and ODS combination. Note the varying $\mathrm{x}$ and $\mathrm{y}$ axis scales.

the regression uncertainty ( $p$-value was reduced from 0.07 to $0.007)$. The linear regression for the US CFC- 11 data set was fit by removing the outlier in Fig. 1, which was considerably outside the $99 \%$ confidence interval. A discussion of how this outlier may have affected the final results is included in the following section.

\section{Results and discussion}

The 2006 US and UK estimates of CFC-11, CFC-12, CFC113 , and $\mathrm{CH}_{3} \mathrm{CCl}_{3}$ landfill emissions are presented in Table 3 . The best estimates use national $\mathrm{CH}_{4}$ emission statistics which subtract recovered and oxidized $\mathrm{CH}_{4}$. The maximum estimates represent the total possible ODS landfill emissions, using the methodology in this study, if all landfill gas produced or volatilized in landfills were emitted to the atmosphere. They are considered to be an upper threshold to the estimates. The US CFC-11 best estimate $\left(0.037 \mathrm{Gg} \mathrm{y}^{-1}\right)$ is significantly lower than the emissions ex-
Table 3. 2006 US and UK MSW landfill emission estimates for CFC-11, CFC-12, CFC-113, and $\mathrm{CH}_{3} \mathrm{CCl}_{3}$.

\begin{tabular}{lrrr}
\hline & \multicolumn{2}{c}{ Estimate Mean } & \\
\cline { 2 - 3 } $\begin{array}{l}\text { Country/ } \\
\text { Compound }\end{array}$ & $\begin{array}{r}\text { Best } \\
\left(\mathrm{Gg} \mathrm{y}^{-1}\right)\end{array}$ & $\begin{array}{r}\text { Maximum } \\
\left(\mathrm{Gg} \mathrm{y}^{-1}\right)\end{array}$ & $\begin{array}{r}\text { 95\% CIs } \\
\text { Upper, Lower }\end{array}$ \\
\hline US/CFC-11 & 0.037 & 0.074 & $+80 \%,-61 \%$ \\
US/CFC-12 & 0.089 & 0.18 & $+148 \%,-93 \%$ \\
US/CFC-113 & 0.0058 & 0.012 & $+148 \%,-93 \%$ \\
US/CH ${ }_{3} \mathrm{CCl}_{3}$ & 0.012 & 0.024 & $+123 \%,-81 \%$ \\
\hline UK/CFC-11 & 0.0082 & 0.027 & $+91 \%,-68 \%$ \\
UK/CFC-12 & 0.032 & 0.11 & $+44 \%,-36 \%$ \\
\hline
\end{tabular}

a Calculated by using the corresponding Best and Maximum estimates in in Table 2 along with the regressions in Fig. 2.

${ }^{\mathrm{b}} \mathrm{CI}=$ confidence interval. Includes the uncertainty in the regression estimates and the uncertainty in the landfill $\mathrm{CH}_{4}$ emission estimates. 
Table 4. Recent observation-based estimates of total US and UK emissions of CFC-11, CFC-12, CFC-113, and $\mathrm{CH}_{3} \mathrm{CCl}_{3}{ }^{\mathrm{a}}$.

\begin{tabular}{lcccc}
\hline $\begin{array}{l}\text { Country/ } \\
\text { Compound }\end{array}$ & $\begin{array}{c}\text { Li et al. } \\
(2005)^{\mathrm{b}}\end{array}$ & $\begin{array}{c}\text { Hurst et al. } \\
(2006)^{\mathrm{c}}\end{array}$ & $\begin{array}{c}\text { Millet et al. } \\
(2009)^{\mathrm{d}}\end{array}$ & $\begin{array}{c}\text { Manning } \\
(2007)^{\mathrm{e}}\end{array}$ \\
\hline US/CFC-11 & 7.3 & $7.0(4.4-9.6)$ & $11(7-14)$ & \\
$\mathrm{US} / \mathrm{CFC}-12$ & 16.4 & $14.2(10.2-18.3)$ & $8.8(0-16)$ & \\
$\mathrm{US} / \mathrm{CFC}-113$ & 0.6 & $1.5(0.6-2.3)$ & $\mathrm{ND}$ & \\
$\mathrm{US} / \mathrm{CH}_{3} \mathrm{CCl}_{3}$ & 2.2 & $3.8(2.6-4.9)$ & $2.8(2-3.5)$ & \\
\hline $\mathrm{UK} / \mathrm{CFC}-11$ & & & & 0.68 \\
$\mathrm{UK} / \mathrm{CFC}-12$ & & & & 0.51 \\
\hline
\end{tabular}

a All estimates are in $\mathrm{Gg} \mathrm{y}^{-1} ; 95 \%$ confidence intervals are shown in brackets if they were given; $\mathrm{ND}=$ not detectable.

b Combines measurements at Trinidad Head, California and Harvard Forest, Massachusetts as explained in Li et al. (2005). Data is averaged over the years 1999-2002 for CFC-12, CFC-11, and CFC113 and 2001-2002 for $\mathrm{CH}_{3} \mathrm{CCl}_{3}$.

c Calculated by multiplying 2003 emission rates derived from the COBRA-NA airplane campaign (Hurst et al., 2006) with a 2003 US population of 290, 796, 023 (US Census Bureau, 2009).

d Combines recent airplane campaigns with a chemical transport model and represents an average of the years 2004-2006 (Millet et al., 2009).

e UK emission are estimated for the year 2005/2006 (updated results from A. Manning (personal communication, 2007) are based on Manning et al., 2003).

pected from instantaneous release of decommissioned appliances (Kjeldsen and Scheutz, 2003). Moreover, the UK best estimates $\left(0.0082\right.$ and $\left.0.032 \mathrm{Gg} \mathrm{y}^{-1}\right)$ are significantly lower than a previous order of magnitude estimate of $1 \mathrm{Gg} \mathrm{y}^{-1}$ for total UK landfill emissions of all CFCs in 1995 (Allen et al., 1997). For the US estimates, CFC-12 had the largest landfill mole fractions and emissions, followed by: CFC$11>\mathrm{CH}_{3} \mathrm{CCl}_{3}>\mathrm{CFC}-113$. This ranking is consistent with default US concentrations (EPA, 2008) and some landfill studies (e.g. EPA, 1995; Allen et al., 1997). However, other landfill studies have detected larger relative concentrations of $\mathrm{CH}_{3} \mathrm{CCl}_{3}$ or CFC-11 (e.g. Deipser et al., 1996; Parker et al., 2002; Scheutz et al., 2008). The US and UK per capita emissions, calculated by dividing the Table 3 estimates by Census data (ONS, 2007; US Census Bureau, 2009), were equal or statistically indistinguishable for CFC$11\left(\mathrm{US}\right.$ and $\mathrm{UK}=0.1 \mathrm{~g}$ person $\left.^{-1} \mathrm{y}^{-1}\right)$ and $\mathrm{CFC}-12(\mathrm{US}=0.3$, $\mathrm{UK}=0.5 \mathrm{~g}_{\text {person }}^{-1} \mathrm{y}^{-1}$ ) partly due to the estimate uncertainties. The UK CFC-12 emission estimates had the narrowest $95 \%$ confidence intervals ( $+44 \%$ and $-36 \%$ ) resulting from the comparatively constant $\mathrm{ODS} / \mathrm{CH}_{4}$ ratios amongst all of the open UK landfill sites.

With our landfill emission estimates, it was possible to quantify the importance of landfills as a source of ODS emissions in the US and UK by comparing our estimates to total country ODS emissions. Table 4 summarizes recent
Table 5. US and UK landfill emissions as a percentage of total country emissions

\begin{tabular}{|c|c|c|}
\hline \multirow[b]{2}{*}{$\begin{array}{l}\text { Country/ } \\
\text { Compound }\end{array}$} & \multicolumn{2}{|c|}{$\%$ of Total ${ }^{\mathrm{a}}$} \\
\hline & $\begin{array}{c}\text { Best } \\
\text { mean (95\% range) }\end{array}$ & $\begin{array}{c}\text { Maximum } \\
\text { mean }(95 \% \text { range })\end{array}$ \\
\hline US/CFC-11 & $0.4(0.1-1.5) \%$ & $0.9(0.2-3) \%$ \\
\hline $\mathrm{US} / \mathrm{CFC}-12^{\mathrm{b}}$ & $1.0(0.04-2.5) \%$ & $2.0(0.1-5) \%$ \\
\hline US/CFC- $113^{\mathrm{c}}$ & $0.9(0.02-\mathrm{UD}) \%$ & 1.7 (0.04-UD)\% \\
\hline $\mathrm{US} / \mathrm{CH}_{3} \mathrm{CCl}_{3}$ & $0.4(0.05-1) \%$ & $0.8(0.1-3) \%$ \\
\hline UK/CFC-11 & $1.2(0.4-3) \%$ & $4.0(1-9) \%$ \\
\hline UK/CFC-12 & $6.3(4-10) \%$ & $21(12-34) \%$ \\
\hline
\end{tabular}

${ }^{a}$ Mean estimates and $95 \%$ confidence intervals calculated by multiplying (Best or Maximum estimate of landfill ODS emissions from Table 3 ) $\times 100 \div$ (mean, maximum or minimum of all US or UK total ODS emission estimates for each compound from Table 4).

${ }^{b}$ For US CFC-12, instead of averaging the three US emission estimates in Table 4 , the most recent estimate of $8.8 \mathrm{Gg}$ was used. See text for an explanation.

c ND in Table 4 was assumed to be equal to zero and $\mathrm{UD}=$ undetermined. See text for an explanation of the upper $95 \%$ confidence intervals.

observation-based estimates of total US and UK ODS emissions. The US estimates span a time period between 19992006, with the oldest estimates listed farther to the left of Table 4. For CFC-11, CFC-113, and $\mathrm{CH}_{3} \mathrm{CCl}_{3}$, there was no sustained increase or decrease in US emissions from 19992006; thus we used the average of all three US estimates to estimate the contribution of landfills to total national emissions. For CFC-12, the total US estimates had a sustained decrease over time; hence we used the most recent US CFC12 estimate from Millet et al. (2009) in subsequent calculations. In addition, we used the highest or lowest $95 \%$ confidence intervals in each row in Table 4 for further calculations with the following exceptions. For the UK gases, a 95\% confidence interval of $10 \%$ was assumed, corresponding to the difference between the two UK estimation methods. For US CFC-12, a lower confidence interval of $8.8 \mathrm{Gg}$ was used for the total country estimates. Based on previously published uncertainty ranges (Hurst et al., 2006; Li et al., 2005; Barnes et al., 2003) and the steady decrease observed in CFC-12 emissions over northwest Europe from 1995-2006 (A. Manning, personal communication, 2007), it seems unlikely that CFC-12 emissions have suddenly dropped to zero in the US.

The UK CFC-12 and CFC-11 total emissions in Table 4 are averages of two estimation methods. The first estimation method uses mole fraction measurements taken at Mace Head, Ireland in combination with inverse modeling as described in Manning et al. (2003). The second estimation method calculates ODS/CO ratios using Mace Head ODS mole fractions and a model-derived $\mathrm{CO}$ time series, and then 


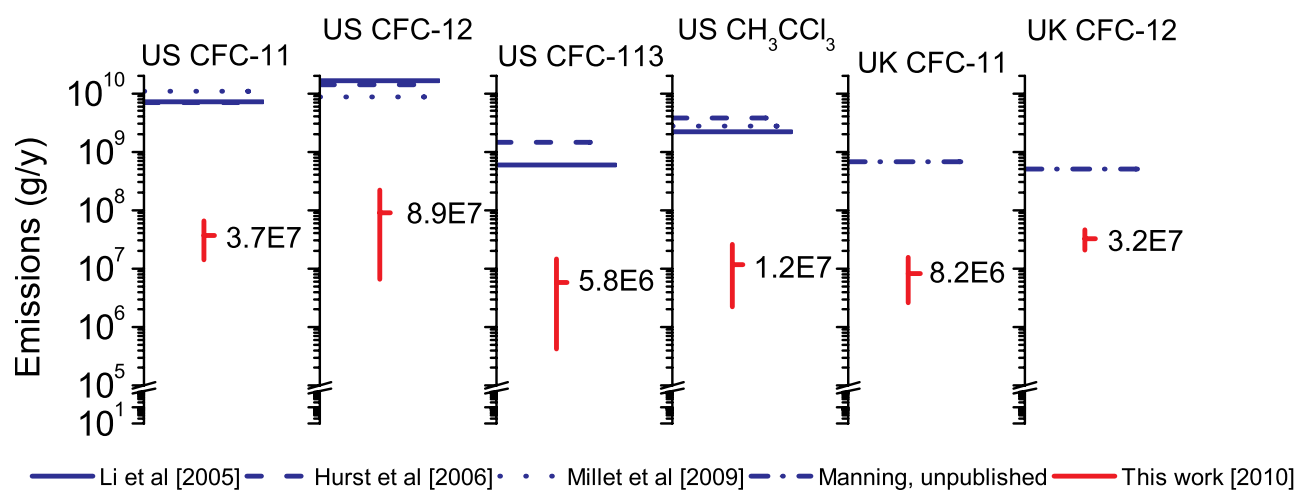

Fig. 3. The 2006 landfill emission estimates (vertical red lines) plotted against total emission estimates from Table 4 (horizontal blue lines). The vertical red lines represent the mean and $95 \%$ confidence interval of the landfill ODS best estimates with the mean value explicitly labeled (Table 3).

uses CO maps from the European Monitoring and Evaluation Programme to extrapolate to the UK scale. The estimates from both methods are within 10\% (A. Manning, personal communication, 2007).

Using the total country estimates (Table 4), we calculated source strengths for our landfill emission estimates in Table 5. The best estimates of US landfill emissions were less than or equal to $1 \%$ of total US ODS emissions for each compound, with an upper limit for CFC-11, CFC-12 and $\mathrm{CH}_{3} \mathrm{CCl}_{3}$ (upper $95 \%$ confidence interval of the maximum estimate) between 3\%-5\%. US CFC-113 was a special case, because the latest total country estimates from Millet et al. (2009) could not detect US CFC-113 emissions which were statistically different from zero. That makes it difficult to say anything about the CFC-113 upper 95\% confidence intervals. It is possible that all lingering CFC-113 emissions in the US are coming from landfills. However, based on total US CFC113 estimates from Li et al. (2005) and Hurst et al. (2006), it seems more likely that landfills are contributing a maximum of $2.5 \%$ to the US CFC-113 emission source.

UK CFC-11 landfill emissions (1.2\%) were within the same range as the US landfill emissions. CFC-12 landfill emissions in the UK were estimated to be a potentially significant fraction of total UK CFC-12 emissions (6.3\% with an upper limit of 34\%). The highly linear correlation between recovered $\mathrm{CFC}-12$ and $\mathrm{CH}_{4}$ for the $\mathrm{UK}$ samples (Fig. 2) lends further credibility to the UK CFC-12 estimates. The difference between the best and maximum percentages was larger for the UK estimates because a larger fraction of landfill gas is recovered (Table 2).

Landfill emission estimates from this study are plotted against the recent US and UK total ODS emission estimates in Fig. 3. Except for UK CFC-12 and possibly US CFC113 , the landfill emission best estimates are $\sim 2$ orders of magnitude below the best estimates of total country emissions. This provides clear evidence that US CFC-11, CFC12, and $\mathrm{CH}_{3} \mathrm{CCl}_{3}$ and UK CFC-11 MSW landfill emissions are a small fraction of total country ODS emissions. More- over, we projected that the methodology used in this study could significantly overestimate CFC-11 landfill emissions and possibly overestimate all US ODS landfill emission, if US closed landfills have lower $\mathrm{ODS} / \mathrm{CH}_{4}$ landfill gas ratios as suggested by Fig. 1 .

ODS landfill emission estimates calculated using waste statistics as an alternative to landfill methane emissions are presented in the SI http://www.atmos-chem-phys.net/10/ 1899/2010/acp-10-1899-2010-supplement.pdf. The results were either equal to the best estimates in Table 3 (UK estimates) or between the best and maximum estimates (US estimates). Because the waste statistics do not account for gas recovery, this provides further evidence that the maximum estimates calculated using landfill methane statistics (Tables 3 and 5) are upper limits and that the true emissions of the ODSs in this study from US and UK landfills are lower than our maximum estimates.

With a small sample size, one of the main concerns was that the data sets were not representative of landfill emissions in the US or UK. The UK regressions for CFC-11 and CFC-12 provided a useful way to check how a much higher $\mathrm{ODS} / \mathrm{CH}_{4}$ ratio would affect US ODS landfill emission estimates (see Figs. 1 and 2). Using the higher UK ODS/CH 4 ratios increased the best estimates of US CFC-11 and CFC-12 landfill emissions to $0.7 \%$ and $1.6 \%$ of total US emissions, respectively. The US maximum landfill source strength increased to $1.3 \%$ (CFC-11) and 3.3\% (CFC-12). Likewise, if we used the US outlier ODS/ $\mathrm{CH}_{4}$ ratio from Fig. 1, US CFC-11 emissions increased to $2 \%$ of total US CFC- 11 emissions. Even these comparisons, which use $\sim 2 \times$ higher $\mathrm{CH}_{4}$ statistics and much different $\mathrm{ODS} / \mathrm{CH}_{4}$ ratios, were still only a small fraction of total US emissions. This indicates that the US estimates are relatively robust to large changes in both the generated $\mathrm{ODS} / \mathrm{CH}_{4}$ ratio and to the national $\mathrm{CH}_{4}$ emission value used with the regressions. Large biases within the data would not change the overall conclusion that landfills are not a significant source of lingering ODS emissions in the US. 
Lastly, although this study was confined to MSW landfills, it seems unlikely that non-MSW landfill emissions would be much different for the CFCs. The Toxics Release Inventory (TRI) provides information submitted by US facilities processing toxic chemicals for the last 20 years. For 2001-2008, chosen for being the longest set of years that TRI lumps together, total landfill disposal is less than $1 \%$ of the total gas released to the atmosphere for the three CFCs in this study (TRI.NET, 2009). Furthermore, during this study we also collected data from seven UK landfills with industrial waste fractions greater than 50\% (not shown). The industrial landfills had $\mathrm{CFC}-11 / \mathrm{CH}_{4}$ and $\mathrm{CFC}-12 / \mathrm{CH}_{4}$ ratios which were indistinguishable from the UK MSW landfill ratios used in our analysis.

Both MSW and non-MSW landfills may be more important sources of other ODSs. For $\mathrm{CH}_{3} \mathrm{CCl}_{3}, 20 \%$ of total reported annual releases was disposed in landfills which accepted hazardous waste (RCRA landfills) during 2001-2008. For HCFC-123, the fraction disposed at RCRA landfills was 98\% over the same time period. Other ODSs with high total disposal rates (over one thousand pounds per year), but low disposal fractions (less than 1\%) relative to their total annual release of the chemical to the atmosphere in the US, are HCFC-22, HCFC-141b and HCFC-142b (TRI.NET, 2009).

\section{Conclusions}

The results support the hypothesis that US and UK MSW landfills are not significant sources of CFC-11, CFC-12, CFC-113, and $\mathrm{CH}_{3} \mathrm{CCl}_{3}$ in the US and CFC-11 and CFC12 in the UK. US MSW landfills were estimated to emit all four compounds at a rate of $1 \%$ or less of total US emissions. The upper $95 \%$ confidence intervals gave slightly more ambiguous results. CFC-12, CFC-11, and $\mathrm{CH}_{3} \mathrm{CCl}_{3}$ were still small percentages of total US ODS emissions $(1 \%-2.5 \%)$, but the upper $95 \%$ confidence interval for CFC-113 could not be determined and may be a greater fraction of total US CFC113 emissions. Likewise, CFC-11 emissions from UK MSW landfills were estimated to be $1 \%$ of total UK CFC-11 emissions and only UK CFC- 12 emissions were estimated to be a higher fraction of total country emissions $(6.3 \%)$. The results were very robust to both the selection of sampled activelymanaged landfills and to the national statistics used for the extrapolation.

The conclusions from this study support the idea that continued emissions in industrialized countries of CFC-11, CFC-12, CFC-113, and $\mathrm{CH}_{3} \mathrm{CCl}_{3}$ are still coming from faster emitting sources such as installation, leakage, and destruction of ODS-containing material as described for the global scale in IPCC/TEAP (2005). However, the potential remains for increased banking of ODSs in both MSW and non-MSW landfills in industrialized countries where landfilling is still commonly practiced, such as the US or UK. Especially in the case of CFC-11, where a significant fraction is used in blown foams which are later landfilled, MSW landfills could become important as repositories of CFC-11-containing products. Hazardous waste landfills may be or become significant sources of $\mathrm{CH}_{3} \mathrm{CCl}_{3}$ and $\mathrm{HCFC}$ emissions and should be investigated in the future. Depending on further refinement of the landfill residence time of CFCs, there could be small, but prolonged CFC emissions from landfills lasting over many decades. It is unclear if landfill emissions have peaked or if the peak is yet to come. If landfill emissions do increase or even maintain their current emission levels in the coming decades, this could be important for stratospheric ozone recovery in polar regions, which is expected to recover to 1980s levels in the year 2065, 16 years later than in the mid-latitudes (WMO, 2007).

Acknowledgements. The research for this study was funded by NASA grants NNX07AE89G and NAG512669 and NSF Grant ATM-0120468 with additional resources from the MIT Joint Program on the Science and Policy on Global Change. In addition, we are thankful to many individuals who assisted with our research: to the US landfill and gas plant operators and managers for their permission to sample and for providing the instantaneous flow rate data for each US landfill; to Brian Holdridge at the Massachusetts Department of Environmental Protection for the Massachusetts waste data; to Stuart James at Viridor Waste Management for providing the UK gas, flow rate, and waste data; and to Alistair Manning at the UK Met Office, whose research was funded by DECC UK government contract GA0201, for providing the total UK ODS emission estimates. Lastly, we would like to thank Stefan Reimann and two anonymous reviewers for providing helpful comments on earlier paper drafts.

Edited by: R. Holzinger

\section{References}

AGAGE: Advanced Global Atmospheric Gases Experiment, ALE/GAGE/AGAGE Data through September 2008, http:// agage.eas.gatech.edu/data.htm, last access: August 2009, 2009.

Allen, M. R., Braithwaite, A., and Hills, C. C.: Trace organic compounds in landfill gas at seven UK waste disposal sites, Environ. Sci. Technol., 31, 1054-1061, 1997.

Arsova, L., van Haaren, R., Goldstein, N., Kaufman, S. M., and Themelis, N. J.: The State of Garbage in America, Biocycle, 49(12), 1-12, 2008.

Barnes, D. H., Wofsy, S. C., Fehlau, B. P., Gottlieb, E. W., Elkins, J. W., Dutton, G. S., and Montzka, S. A.: Urban/industrial pollution for the New York City-Washington, DC, corridor, 19961998: 2. A study of the efficacy of the Montreal Protocol and other regulatory measures, J. Geophys. Res., 108(D6), 4186, doi: 10.1029/2001JD001117, 2003.

Bogner, J., Ahmed, A. M., Diaz, C., Faaij, A., Gao, Q., Hashimoto, S., Mareckova, K., Ripatti, R., and Zhang, T.: Climate Change 2007: Mitigation. Contribution of Working Group III to the Fourth Assessment Report of the Intergovernmental Panel on Climate Change, Chapter 10: in: Waste Management, edited by: Metz, B., Davidson, O. R. Bosch, P. R., Dave, R., Meyer, L. 
A., Cambridge University Press, Cambridge, UK and NY, USA, 2007.

Bousquet, P., Hauglustaine, D. A., Peylin, P., Carouge, C., and Ciais, P.: Two decades of $\mathrm{OH}$ variability as inferred by an inversion of atmospheric transport and chemistry of methyl chloroform, Atmos. Chem. Phys., 5, 2635-2656, 2005, http://www.atmos-chem-phys.net/5/2635/2005/.

Choudrie, S., Jackson, J., Watterson, J., Murrells, T., Passant, N., Thomson, A., Cardenas, L., Leech, A., Mobbs, D., and Thistlethwaite, G.: UK Greenhouse Gas Inventory 1990 to 2006: Annual Report for submission under the Framework Convention on Climate Change, Tech. Rep. AEAT/ENV/R/2582, Department for Environment, Food and Rural Affairs (DEFRA), 2008.

Daniel, J. S., Velders, G. J. M., Solomon, S., McFarland, M., and Montzka, S. A.: Present and future sources and emissions of halocarbons: Toward new constraints, J. Geophys. Res.-Atmos., 112, D02301, doi:10.1029/2006JD007275, 2007.

Deipser, A. and Stegmann, R.: Biological degradation of VCCs and CFCs under simulated anaerobic landfill conditions in laboratory test digesters, Env. Sci. Pollut. R., 4, 209-216, 1997.

Deipser, A., Poller, T., and Stegmann, R.: Emissions of Volatile Halogenated Hydrocarbons from Landfills, in: Landfilling of Waste: Biogas, edited by: Christensen, T., Cossu, R., and Stegmann, R., E \& FN Spon, London, UK, 59-71, 1996.

EIA: Emissions of Greenhouse Gases in the United States 2007, Tech. Rep. DOE/EIA-0573(2007), Energy Information Administration (EIA), Department of Energy, Washington, DC, USA, online available at: http://www.eia.doe.gov/oiaf/1605/ggrpt/index. html, 2008.

EPA: List of Industrial Waste Landfills and Construction and Demolition Waste Landfills, Tech. Rep. 530-R-95-019, PB95208914, Prepared for the US, Environmental Protection Agency by Eastern Research Group, Inc., Lexington, MA, USA, online available at: http://www.epa.gov/osw/hazard/generation/sqg/list/ lfillpdf.pdf, 1994.

EPA: Determination of Landfill Gas Composition and Pollutant Emission Rates at Fresh Kills Landfill: Volume I, Tech. Rep. EPA902-R-95-001a, US Environmental Protection Agency, Washington DC, USA, 1995.

EPA: Background Information Document for Updating AP42 Section 2.4 for Estimating Emissions from Municipal Solid Waste Landfills, Tech. Rep. EPA/600/R-08-116, US Environmental Protection Agency, Washington DC, USA, 2008.

EPA: Inventory of US Greenhouse Gas Emissions and Sinks: 1990-2007; Chapter 8: Waste and Annex 3: Methodological Descriptions for Additional Source or Sink Categories, Tech. Rep. EPA 430-R-09-004, US Environmental Protection Agency, Washington DC, USA, http://epa.gov/climatechange/emissions/ usinventoryreport.html, 2009a.

EPA: Quantifying Uncontrolled Landfill Gas Emissions from Two Florida Landfills, Tech. Rep. EPA/600/R-09/046, US Environmental Protection Agency, Washington DC, USA, 2009b.

EPA: Landfill Gas Emissions Model (LandGEM), version 3.02, http://www.epa.gov/ttn/catc/products.html \\#software, last access: August 2009, 2009c.

EPA: Municipal Solid Waste Generation, Recycling and Disposal in the United States: Facts and Figures for 2007, Tech. Rep. EPA530-R-08-010, US Environmental Protection Agency, Washington, DC, USA, http://www.epa.gov/waste/ nonhaz/municipal/msw99.htm, 2009d.

Giess, P., Bush, A., and Dye, M.: Trace gas measurements in landfill gas from closed landfill sites, Int. J. Environ. Stud. , 57, 65-77, 1999.

Hodson, E.: The Municipal Solid Waste Landfill as a Source of Montreal Protocol-restricted Halocarbons in the United States and United Kingdom, Ph.D. thesis, Massachusetts Institute of Technology, Cambridge, MA, USA, online available at: http: //globalchange.mit.edu/pubs/theses.html, 2008.

Hurst, D. F., Lin, J. C., Romashkin, P. A., Daube, B. C., Gerbig, C., Matross, D. M., Wofsy, S. C., Hall, B. D., and Elkins, J. W.: Continuing global significance of emissions of Montreal Protocolrestricted halocarbons in the United States and Canada, J. Geophys. Res.-Atmos., 111, D15302, doi:10.1029/2005JD006785, 2006.

IPCC/TEAP: IPCC/TEAP Special Report on Safeguarding the Ozone Layer and the Global Climate System: Issues Related to Hydrofluorocarbons and Perfluorocarbons, prepared by Working Group I and III of the Intergovernmental Panel on Climate Change, and the Technology and Economic Assessment Panel, edited by: Metz, B., Kuijpers, L., Solomon, S., Andersen, S. O., Davidson, O., Pons, J., de Jager, D., Kestin, T., Manning, M., and Meyer, L. A., Cambridge University Press, Cambridge, UK and New York, NY, USA, 488 pp., 2005.

Isobe, T., Feigelson, E., Akritas, M. G., and Babu, G. J.: Linear Regression in Astronomy I, The Astrophysical Journal, 364, 104113, 1990.

Jackson, J., Li, Y., Passant, N., Thomas, J., Thistlethwaite, G., Thomson, A., and Cardenas, L.: Greenhouse Gas Inventories for England, Scotland, Wales and Northern Ireland: 1990-2006, Tech. rep., AEA Energy and Environment, Didcot, England, online available at: http://www.naei.org.uk/report_link.php?report id $=527,2008$.

Kjeldsen, P. and Jensen, M. H.: Release of CFC-11 from disposal of polyurethane foam waste, Environ. Sci. Technol., 35, 30553063, 2001.

Kjeldsen, P. and Scheutz, C.: Short- and Long-Term Releases of Fluorocarbons from Disposal of Polyurethane Foam Waste, Environ. Sci. Technol., 37, 5071-5079, 2003.

Li, J. L., Cunnold, D. M., Wang, H. J., Weiss, R. F., Miller, B. R., Harth, C., Salameh, P., and Harris, J. M.: Halocarbon emissions estimated from advanced global atmospheric gases experiment measured pollution events at Trinidad Head, California, J. Geophys. Res.-Atmos., 110, D14308, doi:10.1029/2004JD005739, 2005.

LMOP: Landfill Methane Outreach Program landfill and project database, online available at: http://www.epa.gov/lmop/, last access: August 2009, 2009.

Manning, A. J., Ryall, D. B., Derwent, R. G., Simmonds, P. G., and O'Doherty, S.: Estimating European emissions of ozonedepleting and greenhouse gases using observations and a modeling back-attribution technique, J. Geophys. Res.-Atmos., 108, D144405, doi:10.1029/2002JD002312, 2003.

McCulloch, A. and Midgley, P.: Estimated Historic Emissions of Fluorocarbons from the European Union, Atmos. Environ., 32, 1571-1580, 1998

McCulloch, A., Ashford, P., and Midgley, P.: Historic emissions of fluorotrichloromethane (CFC-11) based on a market survey, Atmos. Environ., 35, 4387-4397, 2001. 
McCulloch, A., Midgley, P., and Ashford, P.: Releases of refrigerant gases (CFC-12, HCFC-22 and HFC-134a) to the atmosphere, Atmos. Environ., 37, 889-902, 2003.

Millet, D. B., Atlas, E. L., Blake, D. R., Blake, N. J., Diskin, G. S., Holloway, J. S., Hudman, R. C., Meinardi, S., Ryerson, T. B., and Sachse, G. W.: Halocarbon Emissions from the United States and Mexico and Their Global Warming Potential, Environ. Sci. Technol., 43, 1055-1060, 2009.

Millet, D. B. and Goldstein, A. H.: Evidence of continuing methylchloroform emissions from the United States, Geophys. Res. Lett., 31, L17101, doi:10.1029/2004GL020166, 2004.

ONS: Mid year population estimates 2006: UK, England, Wales, Scotland and Northern Ireland News Release, online available at: http://www.statistics.gov.uk/pdfdir/popest0807.pdf, 2007.

Parker, T., Dottridge, J., and Kelly, S.: Investigation of the Composition and Emissions of Trace Components in Landfill Gas, Tech. Rep. R \& D Technical Paper P1-438/TR, UK Environment Agency, 2002.

Prinn, R. G., Huang, J., Weiss, R. F., Cunnold, D. M., Fraser, P. J., Simmonds, P. G., McCulloch, A., Harth, C., Reimann, S., Salameh, P., O’Doherty, S., Wang, R. H. J., Porter, L. W., Miller, B. R., and Krummel, P. B.: Evidence for variability of atmospheric hydroxyl radicals over the past quarter century, Geophys. Res. Lett., 32, L07809, doi:10.1029/2004GL022228, 2005.

Rettenberger, G. and Stegmann, R.: Landfill Gas Components, in: Landfilling of Waste: Biogas, edited by: Christensen, T., Cossu, R., and Stegmann, R., E \& FN Spon, London, UK, 51-58, 1996.

Rittmeyer, C. and Vehlow, J.: Decomposition of organohalogen compounds in municipal solid waste incineration plants. Part I: Chlorofluorocarbons, Chemosphere, 26(12), 2129-2138, 1993.
Scheutz, C. and Kjeldsen, P.: Capacity for biodegration of CFCs and HCFCs in a methane oxidative counter-gradient laboratory system simulating landfill soil covers, Environ. Sci. Technol., 37, 5143-5149, 2003.

Scheutz, C., Dote, Y., Fredenslund, A., Mosbaek, H., and Kjeldsen, P.: Attenuation of Fluorocarbons Released from Foam Insulation in Landfills, Environ. Sci. Technol., 41, 7714-7722, 2007.

Scheutz, C., Bogner, J., Chanton, J., Blake, D., Morcet, M., Aran, C., and Kjeldsen, P.: Atmospheric emissions and attenuation of non-methane organic compounds in cover soils at a French landfill, Waste Management, 28, 1892-1908, 2008.

TRI.NET [Internet]. Washington (DC): Environmental Protection Agency (US), Office of Environmental Information - modified 5 December 2009, cited 20 January 2010, available online at: http://www.epa.gov/tri/tridotnet/index.html, 2009.

US Census Bureau, P. D.: Annual Estimates of the Population for the United States, Regions, States, and for Puerto Rico: April 1, 2000 to July 1, 2006 (NST-EST2006-1), online available at: http://www.census.gov/popest/states/NST-ann-est.html, last access: August 2009, 2009.

Wang, J., McElroy, M., Logan, J., Palmer, P., Chameides, W., Wang, Y., and Megretskaia, I.: A quantitative assessment of uncertainties affecting estimates of global mean $\mathrm{OH}$ derived from methyl chloroform observations, J. Geophys. Res.-Atmos., 113, D12302, doi:10.1029/2007JD008496, 2008.

WMO: World Meteorological Organization Scientific Assessment of Ozone Depletion: Global Ozone Research and Monitoring Project-Tech. Rep. No. 50, Geneva, Switzerland, 572 pp., 2007. 